\title{
Xanthogranulomatous salpingo-oophoritis mimicking an ovarian malignancy: a clinical dilemma
}

\author{
Summyia Farooq ${ }^{1 *}$, Farhat Abbas ${ }^{1}$, Rahat Abbas ${ }^{2}$, Ambreen Beigh ${ }^{1}$, Ruby Reshi $^{1}$, \\ Mehnaaz Khuroo ${ }^{1}$
}

\begin{abstract}
${ }^{1}$ Department of Pathology, Government Medical College Srinagar, Jammu and Kashmir, India
${ }^{2}$ Department of Gynecology and Obstetrics, SKIMS Srinagar, Jammu and Kashmir, India
\end{abstract}

Received: 04 February 2020

Revised: 27 March 2020

Accepted: 01 April 2020

\author{
*Correspondence: \\ Dr. Summyia Farooq, \\ E-mail: summiyafarooq@gmail.com
}

Copyright: (c) the author(s), publisher and licensee Medip Academy. This is an open-access article distributed under the terms of the Creative Commons Attribution Non-Commercial License, which permits unrestricted non-commercial use, distribution, and reproduction in any medium, provided the original work is properly cited.

\begin{abstract}
Background: Xanthogranulomatoussalpingo-oophoritis is an uncommon form of chronic inflammation in the genitourinary tract. Its symptoms and radiological findings mimic ovarian malignancy. Aim of this study was to evaluate the clinicopathological pattern of xanthogranulomatous salphingo oophoritis.

Methods: This study was conducted in the department of pathology, Government Medical College, Srinagar. It was a retrospective study done over a period of 5 years, November 2014 to November 2019.

Results: The study was done to evaluate the clinicopathological pattern of 6 cases of rare entity xantogranulomatous salphingo oophoritis diagnosed at a tertiary care hospital. All patients, presented with pain abdomen. All patients were operated due to radiological suspicion of ovarian malignancy. Histopathological examination proved the lesion as xanthogranulomatous salphingo oophoritis.

Conclusions: Xanthogranulomatoussalpingo-oophoritis is a rare condition that is often mistaken for ovarian malignancy clinically and radiologically. Oophorectomy is the recommended treatment but most women are "over treated" with staging laparotomies and hysterectomies that render them infertile.
\end{abstract}

Keywords: Ovarian mass, Xanthogranulomatoussalpingo-oophoritis, Xanthogranulomatous inflammation

\section{INTRODUCTION}

Xanthogranulomatous inflammation is an unusual type of chronic inflammation that leads to tissue destruction of normal tissue of the affected organ. It is characterized by accumulation of lipid laden foamy macrophages (foamy histiocytes with small dark nuclei and clear cytoplasm) intermixed with lymphocytes, giant cells, and plasma cells. ${ }^{1}$ Most common organ affected by xanthogranulomatous inflammation are kidney and gallbladder. $^{2}$ Other organs of xanthogranulomatous inflammation involvement are stomach, anorectal area, bone, urinary bladder, testis, and epididymis. Xanthogranulomatous inflammation of the female genital tract is rare and if found is mostly limited to the endometrium. ${ }^{3}$ Only a few cases involving the ovary and fallopian tube have been reported. ${ }^{4,5}$ Its presentation as a mass lesion in pelvic cavity and infiltration of surrounding tissue can mimic a neoplastic lesion clinically and radiologically. it usually poses diagnostic and therapeutic challenges for the clinician. After extensive search of literature, study found that only few related cases of xanthogranulomatous oophoritis of fallopian tube or ovary have been reported in the literature, study report 6 cases of xanthogranulomatous salphingooophoritis in different age groups, which were clinically and radiologically misdiagnosed as ovarian neoplasms. Histopathological findings revealed 
characteristics features of xanthogranulomatous salphingo oophoritis.

\section{METHODS}

This study was conducted in the department of pathology government Medical College Srinagar Jammu and Kashmir. It was a retrospective study done over a period of 5 years November 2014 to November 2019. Out of 12,000 gynecological specimens excluding other surgical specimens, 3520 cases were ovarian specimens, out of which 6 cases were included in this study which were diagnosed as xanthogranulomatous salphingo oophoritis.

\section{Inclusion criteria}

- Xanthogranulomatous salphingoophritis.

\section{Exclusion criteria}

- All cases of ovarian pathology like functional ovarian cysts, ovarian neoplasms and other infections.

All the six cases had presented as pelvic mass and were suspected as ovarian neoplasms. All the cases were retrieved with the help of medical records. Preliminary data such as age, sex, clinical, radiologic findings gross were recorded from each patient. The resected specimen was then grossed findings like appearance, size was recorded. Slides were reviewed by two pathologists and salphingo oophritis was diagnosed on histopathology.

\section{RESULTS}

This study period of 5 years consisted of six cases, in the age range of 10-32 years with mean age of 22 years. All the six patients presented with pain abdomen and adnexal mass. $3(50 \%)$ out of 6 patients had fever and weight loss.

Table 1: Distribution of cases according to age and laterality.

\begin{tabular}{|ll|l|}
\hline Case number & Age in years & Laterality \\
\hline 1 & 10 & Left \\
\hline 2 & 18 & Right \\
\hline 3 & 21 & Left \\
\hline 4 & 23 & Right \\
\hline 5 & 28 & Left \\
\hline 6 & 32 & Left \\
\hline
\end{tabular}

All the six patients were subjected to ultrasonography and cect abdomen. Four patients had left adnexal mass with extension into surrounding structures. Two cases had right sided adnexal mass. All patients were operated for suspected neoplastic disease. The histopathology in all six cases showed inflammatory infiltrate composed of sheets of foamy histiocytes admixed with numerous plasma cells, lymphoid aggregates, neutrophils and multinucleated giant cells.

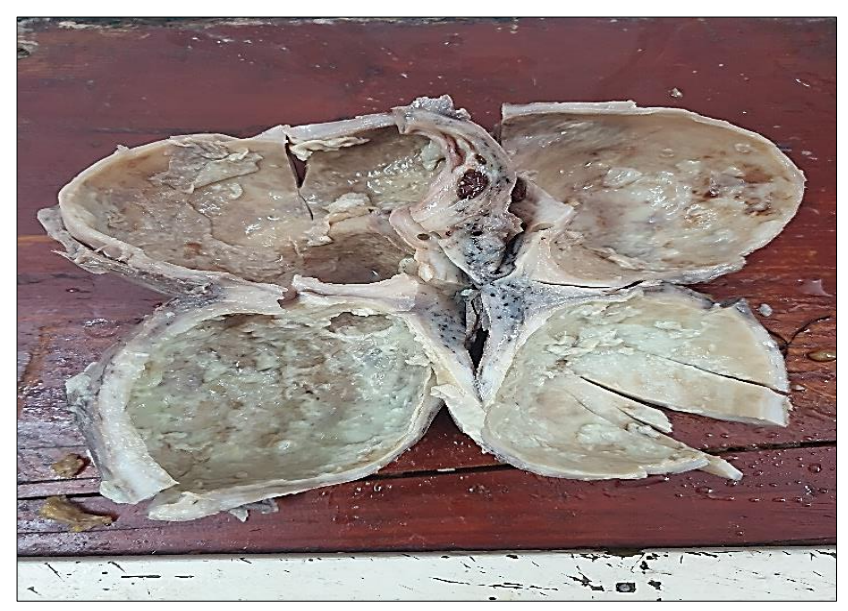

Figure 1: Oophoritis with thick walled cyst containing whitish material.

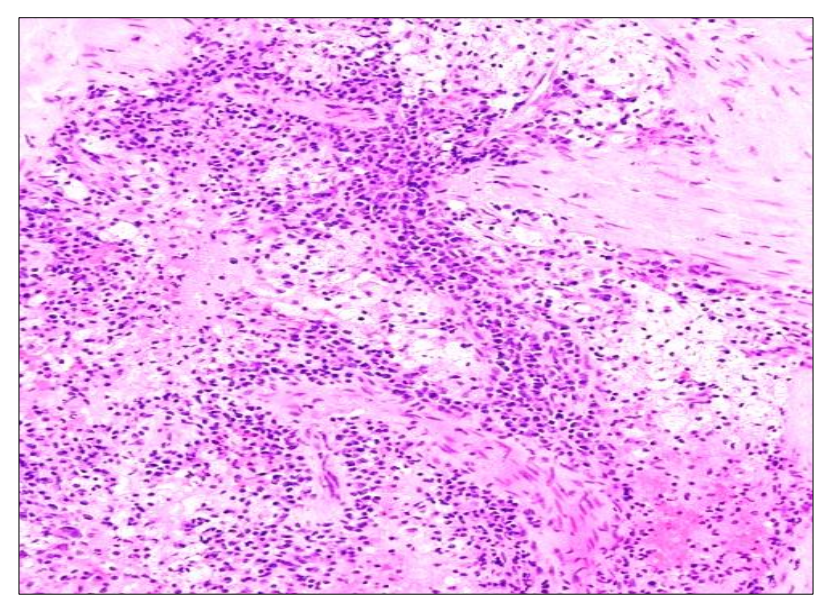

Figure 2: Foamy histiocytes surrounded by mixed inflammatory cells $200 \mathrm{X} \mathrm{H}$ and $\mathrm{E}$.



Figure 3: Histiocytes and plasma cells $400 \mathrm{X} \mathrm{H}$ and $\mathrm{E}$. 


\section{DISCUSSION}

Xanthogranulomatous inflammation of the female genital tract is very rare and if involved is confined to the endometrium. In terms of clinical and intra-operative findings, this chronic inflammatory condition can mimic serious gynecological conditions such as ovarian malignancies. It is most commonly found in kidneys and the gallbladder with rare involvement of female genital tract. However, there are few documented cases of involvement of vagina, cervix, fallopian tube, and ovary. Only a few cases of xanthogranulomatous oophoritis have been reported from India. ${ }^{5}$ The average age of patients with affected ovaries is 31 years, and the youngest case reported was of 2 years old. ${ }^{3,6}$ In this study youngest patient was 10 years old.

Kunakemakorn et al, described the first case of xanthogranulomatous inflammation of serosa of uterus, left fallopian tube, and ovary in his report of inflammatory pseudotumor in the pelvis in $1976 .{ }^{7}$ The pathogenesis of xanthogranulomatous oophoritis is unclear and many theories that are of etiopathogenesis have been postulated, such as theory of infection, endometriosis, intrauterine contraceptive device, inborn errors of lipid metabolism, and drug induced. Amongst these theories, the most accepted theory is of infection, which is supported by clinical evidence of infection and growth of bacteria such as Escherichia coli, Bacteroides fragilis, and Proteus vulgaris from the affected tissue by culture. ${ }^{4}$ Radiological findings of xanthogranulomatous oophoritis may simulate a malignant ovarian neoplasm, due to the involvement of adjacent organs and pelvic peritoneum resulting in adhesions. Grossly, the involved ovary is enlarged and replaced by a solid, yellow lobulated well-circumscribed mass, sometimes involving adjacent organs, there by mimicking malignancy. ${ }^{5}$ Microscopically, there is infiltration of sheets of foamy cells admixed with mixture of inflammatory cells such as lymphocytes, plasma cells, neutrophils with or without multinucleated giant cells. ${ }^{8}$ Foamy histiocytes (xanthoma cells) are histiocytes with abundant lipid-laden cytoplasm having vacuolated appearance, responsible for the yellow color on gross examination.

\section{The emergence of foam cells may be attributed to the following factors}

- Inefficient or inappropriate antibiotics applied in the early phase of infection that resulted in ineffective control of bacterial multiplication

- Presence of a lipid metabolic disorder that induces hyperlipidemia and the foam cells are formed when the lipid deposited is phagocytosed by phagocytes

- The application of intrauterine contraceptive devices or drugs. ${ }^{9}$

Differential diagnosis of xanthogranulomatous oophoritis includes infections like tuberculosis, fungal infections which can be ruled out by culture and special stains for the causative organisms. Malakoplakia is also one of the differential diagnoses. ${ }^{10}$ Wather presumed that malakoplakia and xanthogranulomatous inflammation were identical chronic inflammatory diseases. In malakoplakia, the basophilic cytoplasmic concentric calcific bodies within histiocytes (Michaelis-Gutmann bodies) are found which were absent xanthogranulomatous inflammation ruling out this condition. ${ }^{10}$ Neoplastic conditions with foamy histiocytes include lymphoma or leukemia, malignant small cell tumor and sclerosing stromal tumor. However, microscopy along with special stains confirms the diagnosis. Frozen section may also be used and is very helpful diagnostic modality in cases where xanthogranulomatous inflammation mimics a neoplasm. On, immunohistochemistry histiocytes are positive for CD68. ${ }^{11,12}$ Granulomatous salpingo-oophoritis in surgical pathology practice in developing countries may be seen in many other conditions most common being tuberculosis. Others include a foreign body reaction to suture material introduced at a previous operative procedure, associated Crohn's disease, previous diathermy, a necrotizing reaction following previous surgery, endometriosis and bacterial tubo-ovarian abscess. In few cases no cause could be attributable for the granulomatous inflammation and small cortical granulomas in the ovary are seen called as idiopathic granulomas. ${ }^{13}$ Antibiotic therapy has been attempted, but it has not succeeded in reducing ovarian mass. ${ }^{7}$ Treatment of choice for xanthogranulomatous salpingo oophoritis is salpingo oophorectomy. In this study all the patients were treated surgically due to suspected malignancy. All the six patients had dense adhesions with surrounding structures.

\section{CONCLUSION}

Xanthogranulomatous salpingo-oophoritis is a rare chronic inflammatory condition of the female reproductive tract whose clinical manifestations, imaging modalities and gross features can mimic ovarian malignancy. Thus, a preoperative diagnosis of this entity should be considered to avoid radical surgical treatment.

Funding: No funding sources

Conflict of interest: None declared

Ethical approval: The study was approved by the Institutional Ethics Committee

\section{REFERENCES}

1. Franco V, Florena AM, Guarneri G, Gargano G. Xanthogranulomatous salpingitis: case report and review of the literature. Acta Europaea Fertil. 1990;21(4):197-9.

2. Mittal BV, Badhe BP. Xanthogranulomatous pyelonephritis-(a clinicopathological study of 15 cases). J Post Med. 1989;35(4):209.

3. Jung SE, Lee JM, Lee KY, Han KT, Hahn ST. Xanthogranulomatous oophoritis: MR imaging 
findings with pathologic correlation. Am Roentgenol. 2002;178(3):749-51.

4. Gray Y, Libbey NP. Xanthogranulomatous salpingitis and oophoritis: a case report and review of the literature. Arch Pathol Lab Med. 2001;125(2):260-3.

5. Shukla S, Pujani M, Singh SK, Pujani M. Xanthogranulomatous oophoritis associated with primary infertility and endometriosis. Indian J Pathol Microbiol. 2010;53:197-8.

6. Kaur S, Bodal VK, Bal MS, Bhagat R, Mohi MK, Kaur J. Oophoritis with xanthogranulomatous change - a case report. Res Rev J Med Health Sci. 2013;2:8-9.

7. Kunakemakorn P, Ontai G, Balin H. Pelvic inflammatory pseudotumor: acasereport," Am J Obstet Gynecol. 1976;126(2):286-7.

8. Kalloli M, Bafna UD, Mukherjee G, Devi UK, Gurubasavangouda, Rathod PS. A rare xanthogranulomatous oophoritis presenting as ovarian cancer. Online J Health Allied Sci. 2012;11:11.

9. Zhang XS, Dong HY, Zhang LL, Desouki MM, Zhao C. Xanthogranulomatous inflammation of the female genital tract: report of three cases. J Cancer. 2012;3:100-6.

10. Walther M, Glenn JF, Vellios F. Xanthogranulomatous cystitis. J Urol. 1985;134:7456.

11. Date S, Sulhyan K, Badge S, Gosavi A, Ramteerthkar N. Xanthogranulomatous oophoritis: case report. Indian J Basic Appl Med Res. 2013;7(2):745.

12. Gupta N, Gupta C. Xanthogranulomatous oophoritis masquerading as ovarian neoplasm: report of two cases. Annal Pathol Lab Med. 2015:2(1):C24-7.

13. McCluggage WG, Allen DC. Ovarian granulomas: a report of 32 cases. J Clin Pathol. 1997;50:324-7.

Cite this article as: Farooq S, Abbas F, Abbas R, Beigh A, Reshi R, Khuroo M. Xanthogranulomatous salpingo-oophoritis mimicking an ovarian malignancy: a clinical dilemma. Int J Reprod Contracept Obstet Gynecol 2020;9:1934-7. 